\title{
SYNERGIES, RISKS AND THE REGULATION OF STOCK EXCHANGE INTERCONNECTION
}

by

JOSEPH LEE

In this article, the author discusses the phenomenon of stock exchange interconnection and the synergies that it can bring. He investigates the methods and rationales behind various models currently employed such as the Euronext virtual model, the integration between the London Stock Exchange and the Milan Stock Exchange, and the ASEAN model in Asia. Despite the fact that there are many models of interconnection, none of them are truly interconnected in that they share a common trading platform, a single clearing house, and a single central securities depository. Divergence in national law remains a major obstacle to interconnection. This is because, notwithstanding a certain degree of harmonisation achieved in jurisdictions such as the EU, national laws continue to play an important role in regulating financial market infrastructure such as stock exchanges. Therefore, without a clear regime governing jurisdiction and applicable law, true interconnection is unlikely to be achieved.

\section{KEY WORDS}

Stock Exchanges, Interconnection, Trading Venue, Clearing and Settlement, Risk, Regulation

\section{INTRODUCTION}

As global financial markets have become increasingly interconnected, stock exchanges have followed suit by connecting their operations at the cross-border level to benefit from increased demand for cross-border securities services. To provide some examples, Euronext, a pan-European exchange,

j.lee@exeter.ac.uk, Senior lecturer in law, University of Exeter (UK). This article is an output of a project funded by the British Academy in the UK. 
connects five Eurozone markets: Paris, Amsterdam, Brussels, Lisbon, and London. ${ }^{1}$ The London Stock Exchange and Borsa Italiana (the Milan Stock Exchange) have come together under the umbrella of the London Stock Exchange Group (LSEG), which has been the fifth-largest exchange in the world by market capitalisation since 2008. In the derivatives market, Eurex, Deutsche Börse's derivatives exchange, has launched a common trading platform with the Korean Stock Exchange (KRX) to trade derivatives on both markets. ${ }^{2}$ In the Far East, the Shanghai Stock Exchange (SSE) is now connected to the Hong Kong Stock Exchange (HKEX) for certain equities, allowing investors in the two jurisdictions to purchase shares directly across borders. ${ }^{3}$ Singapore is leading the ASEAN countries in integrating their markets. ${ }^{4}$ Taiwan has established a trade link with Singapore, allowing investors to place orders through the Taiwan Stock Exchange (TWSE) to trade securities listed on the Singapore Stock Exchange. ${ }^{5}$ The EU Commission has long advocated single clearing and settlement to connect exchange-trading platforms. The Target2Securities (T2S) project of the European Central Bank (ECB) has also linked European central securities depositaries (CSDs) to facilitate cross-border securities services.

As market interconnection promotes the free flow of capital, goods, services, and human capital across national borders, exchange interconnection also increases the flow of securities and financial services and reduces market fragmentation. These exchange interconnections (as is

\footnotetext{
Euronext London, a UK licenced exchange operator, is also a member of Euronext and performs listing services in London. See Euronext. (2017) Euronext London. [online] Euronext. Available from: https://www.euronext.com/nl/listings/euronext-london [Accessed 20 September 2017].

2 The London Stock Exchange is connected to the Oslo Exchange. See London Stock Exchange Group. (2017) Norwegian Equity Derivatives. [online] London Stock Exchange Group plc. Available from: http://www.lseg.com/derivatives/lsedm/products/equity-derivatives/ norwegian-equity-derivatives [Accessed 20 September 2017].

3 HKEX-SSX Stock Connect. (2017). [online] Hong Kong Exchanges and Clearing Limited. Available from:http://www.hkex.com.hk/eng/csm/index.htm\# [Accessed 20 September 2017].

4 Grant, J. (2015) Singapore urges closer ASEAN markets integration. Financial Times. Available from: https://www.ft.com/content/50d42aa6-10d1-11e5-9bf8-00144feabdc0 [Accessed 20 September 2017]; See also Wan, W. (2017) Cross-Border Public Offering of Securities in Fostering an Integrated ASEAN Securities Market: The Experiences of Singapore, Malaysia and Thailand. Capital Markets Law Journal, 12 (3), pp. 381-411.

5 Regarding the TWSE-SGX stock connection, See Singapure Exchange. (2016) Taiwan Stock Exchange and Singapore Exchange Sign Strategic Partnership Agreement, TWSE Subsidiary to Join SGX as Remote Trading Member. [online] Singapore Exchange Ltd. Available from: http://www.sgx.com/wps/wcm/connect/sgx_en/home/higlights/news_releases/TaiwanStock-Exchange-and-Singapore-Exchange-sign-Strategic-Partnership-Agreement [Accessed 23 September 2017].
} 
the case for market interconnection) combine the different systems in which they operate into an interactive mode. In turn, this interactive mode can change not only market practices and structures but also legal and regulatory systems ${ }^{6}$ - hence achieving market convergence.

This article considers the rationale, methods, risks and current legal and regulatory framework for stock exchange interconnections. Firstly, it outlines the methods of interconnection. Secondly, it discusses the models of interconnection and identifies the rationale behind some interconnected models and obstacles to cross-border interconnection. Thirdly, it examines the synergies that interconnection can bring. Fourthly, it considers some of the risks of interconnection in terms of market stability and market safety. Fifthly, it discusses how law and regulation, using EU law as an example, can facilitate interconnection. Finally, it provides an outlook on the future of stock exchange interconnection.

\section{WHAT IS AN INTERCONNECTION?}

Interconnection is a generic term that covers mergers, common trading platform sharing, ${ }^{7}$ common clearinghouse sharing (such as the Central Counter Party, $\mathrm{CCP})^{8}$, and the use of a common settlement facility. Some of these interconnection methods have been used to connect different markets, thus facilitating cross-border transactions (e.g. Euronext's Universal Trading Platform, UTP). ${ }^{9}$ In the derivatives market, index derivatives products can be traded across different time zones through common trading platforms. For instance, Eurex and the KRX have pioneered the trading of certain derivative products on a shared trading platform. ${ }^{10}$ In addition to these exchange-led interconnections, dual-listing methods, ${ }^{11}$ which enable shares listed on one stock exchange to be simultaneously traded on another, have long been used to forge

6 Legal and regulatory systems also need to change in order to enable interconnections.

7 In the existing practices, many are still operating separately, but with some arrangements, they achieve the function of interconnections.

8 For instance, Shanghai Stock Exchange (SSE) and Shenzhen Stock Exchange share the same clearing house - China Securities Depository and Clearing Co. (CSDC).

9 Euronext's Universal Trading Platform See Euronext. Universal Trading Platform - New Trading Safeguards. [online] Euronext. Available from: https://www.euronext.com/en/node/ 11277 [Accessed 23 September 2017].

10 Eurex/KRX Link See Eurex Exchange. Eurex/KRX Link. [online] Available from: http://www.eurexchange.com/exchange-en/products/eurex-krx-link

[Accessed 22 September 2017].

11 Dual-listings are not as prevalent as they were. 
interconnections. ${ }^{12}$ The dual-listing concept and method have also been developed further for the listing and trading of foreign securities through Exchange Traded Funds (ETFs). ETFs allow securities traded on an 'A' stock exchange to be packaged according to indices provided by that a stock exchange into a managed fund (normally a company) and then traded on a ' $\mathrm{B}$ ' exchange, hence achieving interconnections. ${ }^{13}$ Furthermore, with distributed ledger technologies (DLTs) such as blockchain, the underlying technology of bitcoin, it is assumed that applications of DLTs can create a blockchain network to facilitate securities transfers. ${ }^{14}$ In this type of common blockchain network, securities issued in different markets can be traded by participants in a more secure and transparent way. Using the same blockchain network by different stock exchanges can also facilitate interconnections. ${ }^{15}$

Each model of interconnection has its own rationale and complex legal arrangements. Indeed, not all these models have achieved trading synergies or truly integrated their markets. A detailed examination shows that certain models of interconnection achieve only organisational synergy. Therefore, I question whether law matters as an obstacle to or facilitator of market interconnections led by exchange operators.

It is therefore necessary to first identify various types of interconnections (models and activities) and their contexts (i.e. their rationales). Second, I outline their endogenous synergies and exogenous benefits (i.e. efficiency to markets) and risks. Third, I examine the law and regulatory environments and identify legal factors that constrain interconnection. Fourth, I present my conclusions on the need for a common method of addressing risks posed by interconnected markets.

12 Ackerly, D. T. and Pan, E. J. (2002) Dual-listing Securities in Europe and the United States. In: Sarah Bolton (ed.) The Complete Guide to Listing on London Stock Exchange. Royal Tunbridge Wells: ISI Publications Ltd.

13 The cross-listing of ETFs is also taking place in the Asia Pacific region. See Jing, L. (2015) Taiwan-Japan ETF Cross-listing Scheme Under Way. Financial Times. Available from: http://www.ft.com/cms/s/0/8f265346-36ac-11e5-b05b-b01debd57852.html?ft_site=falcon\& desktop=true\#axzz4tQzFpt1I [Accessed 22 September 2017]. Although ETF may not be considered as the same product as interconnection, it can also achieve the same effect of interconnections.

14 Euroclear and Oliver Wyman. (2016) Blockchain in Capital Markets: the Price and the Journey. Available from: http://www.dltmarket.com/docs/BlockchainInCapitalMarkets-ThePrizeAnd TheJourney.pdf [Accessed 22 September 2017].

15 DLT is largely focused on post trade issues rather than trading - questionable if this is possible in the med term given divergent laws. 


\section{INTEGRATED MODELS: INTEGRATION OR NOT?}

\subsection{MERGER (LSE-BORSA ITALIANA)}

The LSEG is a multi-local exchange in which the London Stock Exchange (LSE) and Milan Stock Exchange (Borsa Italiana) form part of the LSEG. The group was created through the 2008 takeover of the Milan Stock Exchange by the LSE in the immediate aftermath of the financial crisis. ${ }^{16}$ After the financial crisis, Italian banks were struggling with cash flows and, as the shareholders of the non-listed Borsa Italiana, were keen to sell their shares to the LSE at a large premium. ${ }^{17}$ Presumed synergies arose out of these trading interconnections via the same information technology infrastructure. The Millennium Exchange, a trading platform tool acquired by the LSE from a Sri Lankan developer in 2009, was sold to Borsa Italiana and used for its trading platform. ${ }^{18}$ Almost a decade later, the Borsa Italiana and the LSE remain two separate markets without any linkages in terms of trading, clearing or settlement concerns. ${ }^{19}$ The main synergy achieved is at the organisational level and is based on corporate restructuring. ${ }^{20}$ The two markets maintain their trading cycles of listing, trading, clearing, and settlement. ${ }^{21}$

This begs the question of why the LSE acquired Borsa Italiana. The answer lies in Borsa Italiana's MTS (the wholesale market for the government bonds) and clearinghouse. ${ }^{22}$ When the LSE acquired Borsa Italiana, it did not have its own clearinghouse to clear trades on its markets. Hence, it was thought that acquiring Borsa Italiana and its clearinghouse $(C C \& G)$ would help the LSE Group develop a closed-silo system that could compete with its main rival, Deutsche Börse. ${ }^{23}$ Furthermore, the acquisition of Borsa Italiana prevented Deutsche Börse, its

16 MacDonald, A. (2007) LSE Snags Borsa Italiana, Beating Out NYSE Euronext. The Wall Street Journal, Eastern Edition, 249 (146).

17 Banker (2007) LSE/Borsa Italiana talks, 157 (997), pp. 14-16.

18 The IT system of the Milan Stock Exchange is the same as the LSE, as it has been developed by the LSE. This forced Milan to be acquired by the LSE, as Borsa Italiana must upgrade its IT infrastructure as required by European law.

19 Banker (2007) LSE/Borsa Italiana talks, 157 (977), pp. 14-16.

20 Strategic groups of the two exchanges were combined and the combined strategy group sits in the group headquarters office in London. This has caused the Milan Stock Exchange to introduce restructuring programmes that render every one in four employees redundant.

${ }^{21}$ It should be noted that the Milan Stock Exchange is the listing authority in Italy, whereas the Financial Conduct Authority, rather than the London Stock Exchange, is the listing authority in the UK.

${ }^{22}$ Flinders, K. (2008) London Stock Exchange Gains Clearing Technology. Computer Weekly, p. 6 . 
rival operating under a closed-silo model, ${ }^{24}$ from acquiring this important continental European exchange. Despite this merger within the European common market, no common trading platform has been established, such as the Euronext model's UTP. ${ }^{25}$ Those opposed to such an interconnected platform primarily include Italian-based traders, who fear that an interconnected trading platform based in London could put them at a disadvantage relative to their London counterparts. ${ }^{26}$ Orders placed through Borsa Italiana would be delayed due to distance. Although the LSE proposed delaying orders placed by London-based traders to level the playing field, Milan traders did not consider this a sufficient means of addressing the latency issue.

The LSE acquired LCH. Clearnet, a merged clearinghouse. Clearnet SA was created by Euronext, the Paris Stock Exchange. ${ }^{27}$ To date, there has been no consolidation between the LSE-owned CCP, LCH. Clearnet and the Borsa Italiana-owned CC\&G. CC\&G is not even a CCP that offers clearing services for trading on the LSE London market for its own clearing members. Indeed, there is no interoperability between LCH. Clearnet and CC\&G. Moreover, no access has been granted for LCH. Clearnet to clear trade on Borsa Italiana. The clearing members of the two markets could have benefited from either more consolidated or interoperable clearing services. Furthermore, the settlement of trade in the Italian markets was carried out by Monte Titoli, Borsa Italiana's own CSD. In London, settlement facilities were provided through Euroclear London \& Ireland, a subsidiary of Euroclear SA. In Milan, Monte Titoli, a subsidiary

23 Deutsche Börse operates a closed-silo model, which through subsidiaries executes the entire trading cycle of listing, trading, clearing and settlement; See also a description of the background market prior to the 2008 LSE-BI merger in Zwick, S. (2006) Futures: News, Analysis \& Strategies for Futures, Options \& Derivatives Traders, 35 (4), p. 14.

24 Köppl, T. V. and Monnet, C. (2007) Guess What: It's the Settlements! Vertical Integration as a Barrier to Efficient Exchange Consolidation. Journal of Banking $\mathcal{E}$ Finance, 31 (10), pp. 3013-3033.

25 Euronext. Universal Trading Platform - New Trading Safeguards. [online] Euronext. Available from: https://www.euronext.com/en/node/11277 [Accessed 23 September 2017]; See also Pownall, G., Vulcheva, M. and Wang, X. (2014) The Ability of Global Stock Exchange Mechanisms to Mitigate Home Bias: Evidence from Euronext. Management Science, 60 (7), pp. 1655-1676.

${ }^{26}$ Murray, H., Pham, T. P. and Singh, H. (2016) Latency Reduction and Market Quality: The Case of the Australian Stock Exchange. International Review of Financial Analysis, 46, pp. 257-265.

27 See History of LCH.Clearnet. Clearing houses have been subject to M\&A activities in the exchange industry. When LCH was acquired by Clearnet, the LSE also challenged its independence, as Clearnet was a Euronext subsidiary. See (2003) Entente peu cordiale. Economist. [online] Available from: http://www.economist.com/node/1883659 [Accessed 23 September 2017] 
of the Milan Stock Exchange, provides settlement functions. Such vertical operations (the so-called vertical silo) for servicing the entire lifecycle of the securities trade act as an obstacle to horizontal integration, ${ }^{28}$ as Monti Titoli is unlikely to be consolidated with other CSD such as Euroclear.

\subsection{VIRTUAL EURONEXT INTERCONNECTIONS}

Euronext is the first pan-European exchange network to link five equity markets: Paris, Amsterdam, Brussels, Lisbon, and London. ${ }^{29}$ In 2014, Euronext London received approval from the UK regulator to tap into London's international financial market by providing an entry point for international investors to access its deep liquidity pool obtained through interconnected markets.

Under this model, the five markets remain as different listing venues with a common trading platform. ${ }^{30}$ That said, each market retains its home trading platform. For instance, a Belgian company does not need to go to Paris for its shares to be admitted to trade (listing) and to be traded on the Euronext UTP. Permission to trade is granted by Euronext Brussels, and shares are traded on the same platform, which is achieved through the harmonised single order book. A Belgian investor can purchase French securities by placing an order on the Euronext Brussels that will be routed to UTP. Similarly, a seller based in Lisbon can place an order through Euronext Lisbon to sell Dutch securities that can be matched via a buy order placed through Euronext Paris.

The clearing function is performed by Clearnet SA, a subsidiary of LCH. Clearnet. The settlement of securities is performed by the Euroclear for each of these markets. There is no common settlement facility for this interconnected market because issuing companies and investors prefer national securities to be deposited in their own countries, and currently, no law exists that can safely manage legal risks posed by depositing securities outside of the jurisdiction in which securities are issued.

${ }^{28}$ Köppl, T. V. and Monnet, C. (2007) Guess What: It's the Settlements! Vertical Integration as a Barrier to Efficient Exchange Consolidation. Journal of Banking E Finance, 31 (10), pp. 3013-3033.

29 Because our scale and single order book model is constructed on a Pan-European basis, Euronext represents the deepest source of liquidity in Europe. Higher liquidity levels lead to higher trading levels or stock velocity, tighter spreads on the buying and selling of shares and lower share price volatility. These key factors are crucial in terms of attracting global investors.

30 However, the local rules of each market still apply. 
In this manner, the governing law on trade will depend on the nationality of the securities involved. An order placed through the Paris market to purchase a Belgian security will be governed by Belgian law. Members of the five exchanges are mutually recognised: a member of one of the five markets can place orders in the others. Because there is a common trading platform operating in parallel with domestic trading platforms, market conduct issues can be regulated by national regulators who permit securities access to trading. However, a college of regulators establishes policy criteria. A market surveillance team based at Euronext Paris identifies market misconduct such as market abuse and breaches of market rules. This model serves as the best example of interconnections that allow for exchanges within the network to continue to operate within their own market.

In practice, however, such a model can reduce the functions of smaller exchanges in the interconnected network. The Lisbon exchange had roughly 70 personnel and had roughly 10 remained in 2016. If regional development is a factor to consider in an interconnection model, some revisions may be needed to improve it.

\subsection{ASEAN EXCHANGE INTERCONNECTIONS}

In Asia, stock exchange interconnections are not common. The domestic laws and capital market rules among the largest stock exchanges - the Tokyo Stock Exchange (TSE), Shanghai Stock Exchange (SSE), Hong Kong Stock Exchange (HKEX), Korea Stock Exchange (KRX), and Taiwan Stock Exchange (TWSE) - remain very different. There is no regional consensus on standards in terms of listing prospectuses, disclosure obligations, or cross-border enforcement. As a result, Asian capital markets remain fragmented, and there have been no significant developments in terms of creating a common legal framework for financial market infrastructures. Cross-border securities transactions rely heavily on intermediaries, increasing transaction costs. 
Singapore has taken the lead in terms of forging the ASEAN Exchange interconnections that connect Singapore, Thailand, and Malaysia. ${ }^{31}$ The three countries have signed an agreement to create a Trans-Tasman Mutual Recognition of Securities Offerings (MRSO) regime, whereby companies complying with the agreed-upon prospectus regime can have their shares traded on a common trading platform. ${ }^{32}$ Shares placed on the Thai order book are routed to this trading platform and can be matched by orders placed on the Singaporean order book. However, because of a lack of EU-style legal regimes such as the Prospectus Directive $^{33}$ - giving rise to passporting rights ${ }^{34}-$ and a lack of an effective college of regulators, as is the case for Euronext, ${ }^{35}$ the ASEAN interconnection model has not been successful. In addition to a lack of regulatory frameworks that facilitate interconnections, Thailand and Malaysia fear that such interconnections may cause liquidity fragmentation, limiting the depth capital pool needed to support their domestic markets and raising the question of whether stock exchange interconnections reduce the liquidity of less developed exchanges.

31 Implementation plan to promote the development of an integrated capital market to achieve the objectives of the AEC Blueprint, See ASEAN Capital Markets Forum (ACMF). (2016) The Implementation Plan. [online] Available from: http://www.theacmf.org/ACMF/ report/ImplementationPlan.pdf [Accessed 23 September 2017]; See Park, C.-Y. (2013) Asian Capital Market Integration: Theory and Evidence. [online] Asia Development Bank Economics Working Paper. Available from: http://www.adb.org/sites/default/files/publication/30284/ ewp-351.pdf [Accessed 23 September 2017]; See also Stiglitz, J. E. (2010) Risk and Global Economic Architecture: Why Full Financial Integration May Be Undesirable. The American Economic Review, 100 (2), pp. 388-390 (pointing out the risks of full integration).

32 The Association of Southeast Asian Nations (ASEAN). (2015) ASEAN 2025: Forging Ahead Together. [online] The ASEAN Secretariat: Jakarta. Available from: http://asean.org/storage/ 2015/11/67.-December-2015-ASEAN-2025-Forging-Ahead-Together-2nd-Reprint.pdf

[Accessed 23 September 2017]; See also ASEAN Capital Markets Forum (ACMF). (2016) ACMF Action Plan 2016-2020. [online] Available from: http://www.theacmf.org/ACMF/ upload/acmfactionplan2016-2020.pdf [Accessed 23 September 2017].

33 Directive 2003/71/EC of the European Parliament and of the Council of 4 November 2003 on the Prospectus to be Published when Securities are Offered to the Public or Admitted to Trading and Amending Directive 2001/34/EC. Official Journal of the European Union 31 December. Available from: http://data.europa.eu/eli/dir/2003/71/oj [Accessed 23 September 2017]; International Organization of Securities Commissions. (1998) International Disclosure Standards for Cross-Border Offerings and Initial Listings by Foreign Issuers. [online] Available from: http://www.iosco.org/library/pubdocs/pdf/IOSCOPD81.pdf [Accessed 23 September 2017] (non-financial reporting).

34 There is no automatic mutual recognition of prospectus. Approval is still given by national regulators, and standards may be applied differently by national regulators.

35 There is no supra-national securities agency. 


\subsection{TAIWAN-SINGAPORE CONNECTION}

Taiwan is not an ASEAN country. It has the fifth-largest stock exchange in Asia and the $18^{\text {th }}$ largest stock exchange in the world, measured by the market capitalisation value of the shares traded ${ }^{36}$ as part of its in ternationalisation strategy to increase Taiwan investors' exposure to international markets, in 2016, Taiwan established a Singapore-Taiwan Stock Connect regime to allow investors in the two countries to trade in securities listed on the Singapore Stock Exchange (SGX) and the Taiwan Stock Exchange (TWSE). ${ }^{37}$ The TWSE created a subsidiary, Global Link Securities Co., ${ }^{38}$ which then became a remote trading member of the SGX. Within this model, investors in Taiwan can place orders through the TWSE to trade in securities on the SGX. The original plan was for the SGX to implement the same model, creating a subsidiary that then becomes a remote member of the TWSE. In essence, this is similar to using a third party broker obtaining access in another jurisdiction. However, this can substantially reduce the costs of Taiwan intermediaries for connecting directly with SGX. To date, however, the connection is oriented only southward (the TWSE to the SGX) in that investors in Taiwan can place orders to trade on the SGX but not vice versa. Listings are controlled by their respective authorities, and clearings and settlements are performed by their respective institutions.

This model benefits not only investors in Taiwan in terms of providing more investment targets but also broker-dealers in Taiwan because international investors can use the TWSE as a gateway to access the SGX. However, this model can pose risks in terms of retail investor protection and market stability levels. Retail investors in Taiwan may not have access to direct legal services and enforcement agencies in cases in which there have been securities violations by parties based in Singapore. On the issue of market stability, because the TWSE's subsidiary is a remote member and because the TWSE acts as a guarantee for its subsidiary's default, the TWSE has greater exposure to liability.

\footnotetext{
36 See the estimation by StockMarket.com. (2017). Taiwan Stock Exchange [online] StockMarketClock. Available from: https://www.stockmarketclock.com/exchanges/twse [Accessed 23 September 2017].

37 Loh, J. (2016) Taiwan and Singapore Ink Trading Link. Global Capital (1442).

38 See TWSE. (2016) Taiwan Stock Exchange and Singapore Exchange sign Strategic Partnership Agreement, TWSE subsidiary to join SGX as remote trading member. [press release] 27 January. Available from: http://www.twse.com.tw/en/about/press_room/tsec_news_detail.php?id= 18183
} 


\subsection{EUREX-KRX DERIVATIVES INTERCONNECTIONS}

Derivatives should be treated differently than equities. Derivatives traded on exchanges are products devised from exchanges such as Eurex based on the trading information of equities and other products listed on an exchange such as Deutsche Börse or KRX. For investors to be able to engage in the trade of derivatives outside market time, Eurex and KRX have created a common platform for certain derivatives to be traded without market opening time restrictions. ${ }^{39}$

\subsection{EUROPEAN CENTRAL BANK(ECB) TARGET2SECURITIES (T2S)}

$\mathrm{T} 2 \mathrm{~S}$, launched by the ECB, is a platform linking European Central Securities Depositories for settling securities traded on European platforms. T2S serves as a single platform for settling securities trades ${ }^{40}$ and aims to harmonise European post-trade practices based on barriers identified in the Giovannini reports. ${ }^{41} \mathrm{~A}$ single settlement platform has been proposed by the European Commission as a means of reducing settlement costs since the settlement of securities has been performed by a monopoly of national CSDs and, in some cases, by the same exchange operator of a closed-silo model. The rationale for consolidating CSDs is to enable companies' securities to be traded on different venues outside of national jurisdictions and to be settled at a lower cost outside of the jurisdiction in which securities are issued. ${ }^{42}$

T2S is a platform for linking CSDs operations. In effect, national CSDs outsource their settlement processes to T2S and focus on custody and issuance services. In addition, CSDs offer other services such as asset servicing, securities lending, and collateral management data management (big data) services, ${ }^{43}$ thus moving up the value chain. With the introduction

39 Eurex/KRX Link See Eurex Exchange. Eurex/KRX Link. [online] Available from: http://www.eurexchange.com/exchange-en/products/eurex-krx-link [Accessed 22 September 2017].

40 Mortensen, S. (2015) Reviewing the Implementation of $\mathrm{T}+2$, the Impact on the Industry and What Comes Next (T2S). Journal of Securities Operations \& Custody, 7 (4), pp. 312-318.

${ }^{41}$ The Giovannini Group. (2003) Second Report on EU Clearing and Settlement Arrangements. [online] Directorate-General for Economic and Financial Affairs, European Commission. Available from: http://ec.europa.eu/internal_market/financial markets/docs/clearing/second _giovannini_report_en.pdf [Accessed 23 September 2017].

42 The securities are still deposited in their national CSDs.

43 (2017) The Custodian-bank Business: A Big Deal Roils the Industry's Usually Placid Waters. The Economist. [online] Available from: http://www.economist.com/news/finance-andeconomics/21716051-big-deal-roils-industrys-usually-placid-waters-custodian-bankbusiness [Accessed 23 September 2017]. 
of the European Central Securities Depository Regulation (CSDR), CSDs will have access to clearinghouses (CCPs) and trading venues, ${ }^{44}$ meaning that clients will be presented with more options when choosing a CSD to settle securities trades. ${ }^{45}$ In domestic trade, a link between the exchange and CSD helps investors. However, in cases of cross-border trade, horizontal integration between CSDs brings the best synergies: full technical integration followed by legal integration. ${ }^{46}$ This is the rationale behind the ECB's T2S project.

\section{AIMS AND OBJECTIVES OF AN INTERCONNECTION}

\subsection{TRADING SYNERGIES}

Interconnections enable two or more capital markets operated by stock exchanges to connect. ${ }^{47}$ The combination of two markets generates a deep capital pool, increasing liquidity. Liquidity is a critical ingredient of price discovery that is a function performed by the stock exchange. Therefore, interconnections can augment the efficiency of the price discovery function of exchanges. This is a matter of important social utility in terms of investor protection. When markets are fragmented, there is a disparity in prices, and investors may not secure the best price available for the securities in question, hence failing the best execution obligations. The original aim of the EU Best Execution Rule under MiFID I ${ }^{48}$ was to remediate the problem of market fragmentation resulting from competition between different trading venues generated through market competition.

For issuing companies, interconnections increase their exposure to international markets. ${ }^{49}$ As discussed above, dual-listing methods can be used to indirectly connect capital markets and to increase companies' exposure to individuals other than domestic investors. Interconnections with a common trading platform such as the Euronext UTP grant securities

${ }^{44}$ It is not clear whether there will be any meaningful changes to the current market arrangements.

45 This is at least in theory. However, it will need to be investigated further after the CSDR has been implemented for a period of time.

46 Tapking, J. and Yang, J. (2006) Horizontal and Vertical Integration in Securities Trading and Settlement. Journal of Money, Credit \& Banking, 38 (7), pp. 1765-1795.

47 See the Euronext UTP for equities and the KRX-Eurex for derivatives.

48 Ferrarini, G. and Moloney, N. (2012) Reshaping Order Execution in the EU and the Role of Interest Groups: from MiFID I to MiFID II. European Business Organization Law Review, 13 (4), pp. 557-597.

${ }^{49}$ Companies listed on the SGX can benefit from Taiwan's larger capital pool through the SGX-TWSE connection. 
listed on the five markets access to investors in different geographic markets. In the TWSE-SGX southward connection, Singaporean companies now have access to investors in Taiwan. As is the case with the ASEAN model, Thai and Malaysian securities can access international investors based in Singapore. In the failed merger between the LSE and Deutsche Börse, were these two markets permitted to interconnect to create one of the largest equity markets in the world, securities arbitrage caused by market fragmentation could be limited, while investors' investment targets were increased.

The LSE-Borsa Italiana merger did not bring about such trading synergies, as no common trading platform and order routing methods have been implemented.

\subsection{CLEARING SYNERGIES}

Transaction costs can be reduced by sharing a common clearing platform. ${ }^{50}$ For instance, traders of numerous trading venues can use a single CCP to clear their trade. For instance, Traders from both SIX Swiss and LSE or from BATS Chi-X, and NSDAQ OMC can choose a single CCP such as LCH, SIX $x$-clear or EMCF to clear trades. In Euronext Paris, clearing is performed by Clearnet SA as the sole CCP. The proposed merger between LSE and Deutsche Börse, though failed to obtain approval, would have resulted in clearing synergies in which a single clearinghouse can act as a CCP to clear the trade of securities listed on the two markets. Such synergies would substantially reduce transaction costs since clearing represents $40 \%$ of the total trading cost.

A common CCP for different trading venues can reduce margins and collaterals needed by traders operating in two markets. However, a single CCP within the same trading platform can increase costs due to a lack of competition. This problem can be remedied by creating open access, as required under EMIR and MIFIR, to more clearinghouses. To create competition, clearinghouses need to create interoperating linkages so that traders can choose their own preferred CCP to clear trades. However, there are concerns that such inter-linkages can increase risks

${ }^{50}$ For information on the equities market, see (2011) EMCF Says Yes to CCP Interoperability. Global Investor. 245, p. 43. For information on the derivative market, see Himaras, E. (2010) Super-CCP Model Could Spur Interoperability: ISDA. Derivatives Week, p. 15; for a general analysis, see de Meijer, C. (2010) Are We Facing European CCP Interoperability Regulation?. Journal of Securities Operations \& Custody, 3 (1), pp. 55-65. 
of contagion while spurring over-collateralisation. ${ }^{51}$ These links could spread systemic risk with the bankruptcy of an interconnected $\mathrm{CCP}$, which could very quickly infect every interconnected entity. ${ }^{52}$ ECB acts as a liquidity provider in time of crisis and its location policy on the $\mathrm{CCP}$ will affect the ways in which CCPs operate and their interconnections.

\section{RISK OF INTERCONNECTIONS}

\subsection{MARKET STABILITY AND DEFAULT RISK}

When two markets are interconnected by a common trading platform, default risk can spread across the two markets. Default can occur when one party fails to fulfil its obligations, creating a blockage in the trading system. At worst, such a failure to fulfil trade obligations can cause a run because another party's trade depends on its completion. As is the case in a securities market, having an entity acting as a CCP in all transactions can mitigate default risks. When two exchange-trading platforms interconnect, their CCPs must be interoperable to reduce transaction costs, enabling their clearing members to trade on an interconnected common trading platform. To manage the default risk spread across the two markets, CCPs of the interconnected market must have 1) rules dealing with trade defaults as an important risk management tool; 2) a robust recovery and resolution regime to address the insolvency of their clearing members; and 3) strong lines of defence against trading defaults resulting from the insolvency of clearing members. Normally, losses are covered by defaulting the member's own collateral, the CCP's own money and the clearing members' collective fund.

An interconnected trading platform would require the formation of an interconnected clearing platform by creating an inter-linkage between CCPs. This type of interoperable linkage is created when a CCP becomes a clearing member of another CCP. Each interoperable CCP provides collateral deposited with a third party, i.e. Clearstream Luxembourg. Because the insolvency of a CCP will cause a systemic run, the CCP's solvency requirements, governance, and risk management with clearing

51 However, in preventing the risk of contagion, an overcollateralization problem may arise. Mägerle, J. and Nellen, T. (2011) Interoperability Between Central Counterparties. Swiss National Bank Working Papers. 12, pp. 1-28.

52 Farrell, S. (2014) Too Important to Fail: Legal Complexity in Planning for the Failure of Financial Market Infrastructure. Journal of International Banking Law and Regulation, 29 (8), pp. 461-470. 
members through collateral provisions and margin calls are critical in preventing the $\mathrm{CCP}^{\prime}$ s failure.

Although competition between CCPs can reduce transaction costs and thus benefit consumers, such competition can increase insolvency risks because as smaller CCPs enter the clearing market, dispersed liquidity can increase the chances of a CCP's insolvency. A CCP's insolvency will affect other interoperable CCPs. Therefore, a balance must be struck between 1) risks of non-competition between $\mathrm{CCPs}$ and 2) risks of contagion resulting from the insolvency of an interoperable CCP. Another issue concerns whether CCP monopolies or oligopolies may create too-big-to-fail risks and moral hazards through which clearing members or trading venues fail to do their due diligence in vetting the solvency of a CCP. Therefore, financial regulators and supervisors should give special attention to a CCP that is of substantial systemic importance.

\subsection{MARKET CONFIDENCE}

\subsubsection{TRADE TRANSPARENCY}

Trading transparency facilitates price discovery, a function of exchanges. When pre-sale disclosures are not made, such an important function can be distorted, rendering investors unable to obtain the best price available. However, pre-sale disclosure can disturb the market and spread panic. For instance, institutional investors engage in block trades and the disclosure of trades - often at a discount - to the market before execution can influence the market price. However, each country employs its own rules and positions in dealing with such issues. The UK is in favour of non-disclosure, whereas Germany and France are more in favour of transparency. In the US, it is based on a competitive model rather than the EU style of bulletin board. There are also policy concerns. For instance, in the fixed-income market, it is said that pre-trade transparency can reduce liquidity. Therefore, in an interconnected trading platform, a set of common rules must be in place to guide investors. ${ }^{53}$ In cases of post-trade transparency, a common trade repository ${ }^{54}$ for an interconnected trading

53 However, one should also consider the specificity of different product markets, i.e.. equities and bonds; liquid and illiquid markets.

54 For instance, there is the consolidated tape in the EU. See European Securities and Markets Authority (ESMA). (2017) MiFID II: ESMA Issues Final Specifications for Non-equity Tape Test. [online] Available from: https://www.esma.europa.eu/press-news/esma-news/mifid-iiesma-issues-final-specifications-non-equity-tape [Accessed 23 September 2017]. 
platform must be in place to ensure the final price agreed upon to inform the market.

\subsubsection{CORPORATE TRANSPARENCY}

Unlike trade transparency, corporate transparency requires companies to disclose corporate information according to accounting standards and reporting rules. When standards differ, investors can lose confidence in not only the securities in question but also the overall quality of securities on the market. When two markets have diverse corporate reporting rules and different enforcement regimes, investors can have reduced confidence to trade these securities on an interconnected platform. Moreover, to protect retail investors, regulators of a market with higher standards may prevent the market from creating a common trading platform, such as the Euronext UTP, to trade the securities of another market that maintains less stringent corporate reporting standards. This problem is also seen in cross-listing cases in which company's shares are listed and traded on several markets. The company may make a disclosure to its competent authority, however, fail to make the similar disclosure to that of another. This can happen when disclosure rules differ in the two markets or the authorities take different approaches to corporate transparency. In extreme cases, a company shares can be suspended from trading by the decision of the competent authority due to lack of transparency, while shares continue to be traded on another. This shows that a lack of regulatory convergence and regulatory collaboration can lead to damages to investors. Such a risk will reduce the willingness to engage in cross-border trade.

Furthermore, investors need to receive notices to be able to exercise corporate actions in a timely manner. How should the investor receive information at the cross-border level? Who are the actual investors entitled to hold the issuing companies to accountable for the loss of entitlements? How are the language and tax barriers to be overcome? There are different ways as to how the intermediaries such as custodian banks operate to facilitate corporate actions. Without a harmonised approach, there is a risk that the investor will not be protected in relation to their legal and economic entitlements. 


\subsubsection{BEST EXECUTION RULE AND CONSUMER PROTECTION}

Investment banks and brokers may hold securities themselves. When they act on behalf of their investor clients to purchase securities, they may obtain securities not in an open market, and therefore, they may not obtain the best price available on the market. Because retail investors are consumers in the securities markets, it is important to secure their willingness to participate in the securities market. A lack of consumer protection in the securities market will affect overall liquidity levels. To address this liquidity risk, Best Execution Rules require brokers to search for the best price available on different trading venues, clearing houses, settlement facilities, and custodians all in the interest of customers. ${ }^{55}$ This rule is important when the two exchanges' trading platforms are interconnected. If one market does not employ such a rule, an intermediary such as an investment bank (through systematic internalization, SI) may offer securities to investors through securities it has held instead of seeking a quote from alternative trading platforms. ${ }^{56}$ In some markets, such as Taiwan, there is still a concentration rule which prohibits securities to be traded outside the exchange i.e. an alternative trading platform. An interconnection between the markets will need to adopt similar approaches to competition and consumer protection to achieve the intended synergies.

\subsubsection{CONFLICT OF LAWS}

Conflict of laws risks can arise when transactions are made by parties in different jurisdictions. In an interconnected trading platform, parties must determine which law applies and which regulatory agencies will have the power to supervise, investigate and impose sanctions. A buy order can be placed through an exchange based in country a and matched by a sell order through an exchange based in country $\mathrm{B}$. The trading platform can be located in country C. Conflict of laws rules must address 1) which law governs contracts and 2) which regulator addresses issues of misconduct such as cases of market manipulation. Without this legal certainty, investors will not be willing to trade on an interconnected platform. Without rules

55 If a product is tradable in multiple trading platforms which have different post trade arrangements the executable price may seem good but is eroded by the post trade costs.

56 However, this duty may be overridden when parties introduce their traders to orders placed in a particular trading venue. 
detailing each regulator's powers, investors may not know what redress they may pursue.

This is the area where a harmonized private law can increase the effectiveness of market interconnections. That is if contract law, tort law, regulatory regimes are the same in these three countries, investors can obtain the same redress no matter which law of the country applies. ${ }^{57}$ Hence, common approaches in this area can reduce risks. On the enforcement side, a model of a college of regulators [i.e. similar to the structures of the European Securities and Markets Authority (ESMA), the European Banking Authority (EBA), and the European Insurance and Occupational Pensions Authority (EIOPA)] can be introduced to facilitate bilateral or multilateral interconnections. However, the harmonisation of private law can be a slow process, and the determination of an agreeable regulatory structure also requires a long period of political negotiation.

\section{CURRENT REGULATION}

The harmonisation of rules can facilitate system convergence to create market infrastructure connectivity. I will use some of the measures aimed at forging market interconnections introduced by the European Union.

\subsection{FREE MOVEMENT OF CAPITAL AND PASSPORTING RIGHTS FOR ISSUERS}

National regulators focus less on competition among exchanges within the national market and more on making regulatory regimes competitive so as to attract foreign capital beyond borders [e.g. motivating foreign companies to list their securities on their national primary or secondary boards for primary or secondary listings (dual-listing)]. To break through national regimes aimed at protecting national exchange operators, EU law has facilitated the free movement of capital and competition among different market operators across the EU through the Prospectus Directive ${ }^{58}$

57 See the case of the Common European Sales Law.

58 Directive 2003/71/EC of the European Parliament and of the Council of 4 November 2003 on the Prospectus to be Published when Securities are Offered to the Public or Admitted to Trading and Amending Directive 2001/34/EC. Official Journal of the European Union 31 December. Available from: http://data.europa.eu/eli/dir/2003/71/oj [Accessed 23 September 2017]. 
and Transparency Directive ${ }^{59}$. The combination of the Prospectus Directive and Transparency Directive establishes a uniform capital market across the EU to grant European issuers access to European capital markets with relative ease. The Prospectus Directive ${ }^{60}$ and the Transparency Directive $^{61}$ allow securities approved for listing in one jurisdiction to be offered and traded in another jurisdiction's market without the need for further regulatory approval. The Transparency Directive and Transparency Directive Regulations ${ }^{62}$ require issuers of securities admitted to regulated markets in the EU to ensure appropriate transparency levels for investors through the regular flow of information by disclosing periodic and on-going regulated information and by disseminating such information to the public throughout the EU. The creation of the European Electronic Access Point (EEAP) by the European Securities and Markets Authority will provide access to all published regulatory information via each Member State's storage service. ${ }^{63}$ This enables companies to disseminate information in a timely fashion through their home member states and across the EU.

However, because there is only a minimum harmonisation rule on continuing disclosure obligations under the Transparency Directive, companies with securities traded on multiple regulated markets must

59 Directive 2013/50/EU of the European Parliament and of the Council of 22 October 2013 amending Directive 2004/109/EC of the European Parliament and of the Council on the harmonisation of transparency requirements in relation to information about issuers whose securities are admitted to trading on a regulated market, Directive 2003/71/EC of the European Parliament and of the Council on the prospectus to be published when securities are offered to the public or admitted to trading and Commission Directive 2007/14/EC laying down detailed rules for the implementation of certain provisions of Directive 2004/109/EC. Official Journal of the European Union. 6 November. Available from: http://data.europa.eu/eli/dir/2013/50/oj [Accessed 23 September 2017].

60 For an example of how passporting rights operate in cross-border securities, see Ferran, E. (2007) Cross-border Offers of Securities in the EU: the Standard Life Flotation. European Company and Financial Law Review, 4 (4), pp.461-490; for the legislative history of the European markets regulation, see Ferrarini, G. (2002) Pan-European Securities Markets: Policy Issues and Regulatory Responses. European Business Organization Law Review, 3 (2), pp. 249-292.

61 Fleischer, H. and Schmolke, K. U. (2011) The Reform of the Transparency Directive: Minimum or Full Harmonisation of Ownership Disclosure?. European Business Organization Law Review, 12 (1), pp. 121-145.

62 The Transparency Regulations 2015, SI 2015/1755. United Kingdom of Great Britain and Northern Ireland. London: The Stationery Office. In English. Available from: http://www.legislation.gov.uk/uksi/2015/1755/pdfs/uksi_20151755_en.pdf [Accessed 23 September 2017].

63 European Securities and Markets Authority (ESMA). (2015) Final Report: Draft Regulatory Technical Standards on European Electronic Access Point (EEAP). [online] Available from: https://www.esma.europa.eu/sites/default/files/library/2015/11/2015-1460_-_esma_final_ report_on_draft_rts_on_eeap.pdf [Accessed 23 September 2017]. 
comply with more than one continuing disclosure regime, generating higher costs than those when securities are traded in a single venue.

\subsection{PROMOTING COMPETITION}

\section{IN TRADING, CLEARING AND SETTLEMENT}

Regulation can facilitate interconnections while creating obstacles to the formation of interconnection. Because many countries' stock exchanges are still considered national infrastructure and operate as monopolies, national government's views on the role of and on its interest - both regulatory and revenue-wise - in the stock exchange influence the models of linkages that their stock exchanges can have with others.

However, transnational regulators such as EU agencies and the International Organization of Securities Commissions (IOSCO) employ different regulatory policies from those of national regulators, which may focus on national competitiveness (how their market operators can win) rather than on competition at the cross-border level. Even between transnational regulators, regulatory objectives vary: IOSCO focuses on risk, ${ }^{64}$ whereas EU regulators, in addition to risk, monitor competition in securities markets. The EU has the objective of rendering EU securities markets more integrated so that they can compete with markets in countries such as the USA. This objective has led to the formation of measures aimed at the gradual liberalisation of the financial market infrastructure sector. MiFID I, by dispensing with the 'concentration rule', allows alternative trading venues such as Multilateral Trading Platform (MTF) to compete with traditional exchanges' trading platforms. In turn, alternative trading venues have significantly reduced trading fees, ${ }^{65}$ causing exchanges to focus on other areas of the value chain (e.g. clearing and data management services). In the clearing sector, MiFID I and MiFID II open up competition in the clearing sector through 'open access' and 'interoperability'. Open access enables clearing houses to have access to the exchange-controlled trading venues. Interoperable linkages between clearinghouses enable clearinghouses to net trade by parties that use different trading venues.

${ }^{64}$ Karmel, R. S. (2012) IOSCO's Response to the Financial Crisis. Journal of Corporation Law, 37 (4), pp. 849-902.

65 Geranio, M. (2016) Evolution of the Exchange Industry: from Dealers' Clubs to Multinational Companies. Switzerland: Springer International Publishing. 
To maintain the sustainability of alterative trading venues, open access also grants alternative trading venues access to clearing facilities.

\subsection{TRADING TRANSPARENCY}

Trading transparency facilitates exchange price discovery. MiFID imposes such requirements on both the sell side and the buy side, ${ }^{66}$ which is particularly important when the same types of securities can be traded on different venues because trading transparency can mitigate the risks of arbitrage and enable traders to fulfil their obligations of optimal execution for customers. ${ }^{67}$

However, there is no agreement on the impact of trading transparency on market stability. It is argued that although pre-trade disclosure can increase price transparency, the disclosure of large block trades can create instability in the market. Because of such uncertainties, a compromise has been made pursuant to which pre-trade disclosure applies only to certain trading venues such as equities traded on the regulated market. ${ }^{68}$

MiFID II also requires post-trade transparency and trade reporting to ARMs (approved reporting mechanisms) such as UniVista ${ }^{69}$ can operate throughout Europe. Reporting entities under MiFIR are both 'legal' and 'natural' persons. Legal persons must use a Legal Entity Identifier (LEI). ${ }^{70}$ Natural persons must use a unique number. ${ }^{71}$ Firms can no longer select their own identifiers. In the UK markets, the National Insurance Number has been chosen for the UK as a LEI, and the user passport number for those outside of the European Economic Area.

66 Position limits in MiFID II will affect fund managers who trade in commodities derivatives. Of course, firms trading these instruments will also have to report their positions.

67 Art. 21 MiFID I; However, over-reporting is being clamped down on now. If data are over-reported, the will must re-review and report them.

68 European Securities and Markets Authority (ESMA). (2015) Regulatory Technical and Implementing Standards - Annex I: MiFID II/MiFIR. [online] Available from: https://www.esma.europa.eu/sites/default/files/library/2015/11/2015-esma-1464_annex_i__draft_rts_and_its_on_mifid_ii_and_mifir.pdf [Accessed 23 September 2017].

69 See London Stock Exchange Group. (2015) MIFID II: An Update on its Status and Impact. [online] London Stock Exchange Group plc. Available from: http://www.lseg.com/marketsproducts-and-services/post-trade-services/unavista/resources/mifid-ii-update-its-status-and -impact [Accessed 23 September 2017].

70 Changes in the MiFID I and MiFIR: a massive increase in the number of reportable financial instruments, a significant increase in types of transactions to be reported, a large increase in the number of fields in a transaction report (24 data fields increases to 81 ), significant impacts on entities with reporting obligations, and (including those of the buy-side), safe betting at the moment of over reporting. Certain regulators do not prefer this, but it is not a breach, whereas under-reporting is.

71 MiFIR encourages LEI use. 
EMIR also requires trade reporting, and yet, the objectives are different from those of MiFIR. EMIR focuses on the visibility of systemic risk and position exposure, whereas MiFIR is more focused on the detection of market abuse. There has always been a wish for the two to be converged, and thus, a person can report once to one ARM.

These regulations allow interconnected markets to operate using the same approach to transparency. This can reduce arbitrage and render the function of exchange price discovery more efficient.

\subsection{MARKET STABILITY, RISK OF CONTAGION, AND ENTITY GOVERNANCE}

\subsubsection{REGULATED MARKETS}

Market connectivity occurs when financial market infrastructure providers make linkages to spur cross-border trade flows. These providers must be resilient to cope with market eventualities. The UK regulatory regime, under the Financial Services and Markets Act 2000, can offer some guidance. Currently, 'fit and proper' rules; organisational rules addressing conflicts of interest, management risks, the adoption of trading rules, and fiscal resources; and market monitoring rules are imposed through regulated market management and in regulated markets. Regulated markets are traditionally known exchanges. ${ }^{72}$ These rules also apply to alternative trading systems, clearinghouses, securities depositories, and other settlement systems. When a regulated market wishes to make a connection with a third-country market, the third country will need to have equivalent regimes for the markets to operate such an interconnection.

\subsubsection{CCP}

On the trading side, default risk can cause a run on the system. Hence, on-exchange and alternative venue trades must be cleared by a clearinghouse. ${ }^{73}$ The CCP acts as an important entity that manages default risks of trade. Accordingly, the $\mathrm{CCP}$ will assume a concentration

\footnotetext{
72 Investment exchanges - The FSA (29 S; s 285A (1) of FSMA 2000) has the power to make additional rules. See The Financial Services Act 2012 (c. 21). United Kingdom of Great Britain and Northern Ireland. London: The Stationery Office. In English. Available from: http://www.legislation.gov.uk/uksi/2015/1755/pdfs/uksi_20151755_en.pdf [Accessed 23 September 2017].

73 Currently, there is no legal obligation to do so for trades on alternative trading venues.
} 
of risks that can affect market stability levels. Because CCPs provide a trade guarantee, they are subject to more rigorous governance scrutiny under MiFIR. ${ }^{74}$ Whereas CCPs forge interoperable linkages to ease cross-border securities trade, the insolvency of their members and their own risks of insolvency should not affect 1) smooth trading and 2) the entitlements of end investors. Hence, the internal governance of CCPs, margins, collateral levels required for clearing members, clearing member default and close-out rules, and the enforceability of contracts involving clearing members within and outside of the jurisdiction of a trading venue become pertinent for market stability. Unlike the case for regulated exchanges, there are no passporting rights for CCPs. However, EMIR effectively gives a passporting right when a clearinghouse obtains a QCCP status. ${ }^{75}$ In other words, a CCP will need to obtain approval from a competent authority of the market in which it operates. This approval can increase the cost of operations while limiting competition.

However, the regulatory objective of market stability can be translated into different types of provisions. Market stability, such as market confidence, is a broad term that can capture different themes from solvency measures to investor protection regimes.

\subsubsection{CSD}

The CSD processes the settlement of securities trade and provides for settlement finality. It records information on the ownership of securities and may own securities. CSDR regulates how CSD should protect assets and functions of ownership registration. Because European central securities depositories operate on different models, legal relationships between a CSD and its members and between a CSD and end investors vary. Furthermore, CSDs have no passporting rights. Therefore, these differences affect standards for their services, their liabilities towards stakeholders, and enforcements against them. For cross-border securities transfers, International Central Securities Depositories (ICSDs) serve as important intermediaries that link domestic CSDs. In structures in which CCPs begin to interoperate, ICSDs protect the assets of collateral provided

${ }_{74}$ CCP - The PRA (s 285A (2) of FSMA 2000) has the power to make additional rules.

75 For QCCP status under EMIR see LCH The Markets' Partner. (2016) Regulatory Framework and QCCP Status of LCH. [online] Available from: http://www.lch.com/documents/731485/ 762558/regulatory-framework-and-qccp-status-of-lch-final.pdf/5d274c8f-03bb-4647-a69eecf0000ad365 [Accessed 23 September 2017]. 
by interoperable CCPs. The CSDR regulates the governance, conduct, and management of CSDs. Clawback risks for cases involving the insolvency of a member of an CSD are addressed through the Financial Markets and Insolvency (Settlement Finality) Regulations of 1999, which do not allow a trade to be revoked once it has been settled. In terms of the applicable law, the EU member states currently follow the Place of Relevant Intermediary Approach (PRIMA) method under EU law, whereby applicable laws for securities settlement are governed under the laws of the country in which the accounts are maintained. ${ }^{76}$ As a result, parties cannot freely dispose of the applicable law through an agreement. Under the PRIMA approach, insolvency issues are governed by laws of the country in which the accounts are maintained.

That said, private law continues to affect standards of regulation in this area. When a private law model recognises pledges of digital securities, the risk regulation of the CSD will be less robust, as pledges will not increase prudential CSD risks. When a private law model does not recognise pledges of digital securities, the CSD will hold assets as its own, which will increase the prudential risks of the entity, therefore placing considerable CSD collateral requirements on Central Banks. There is no harmonised means of assessing CSD risks. The European financial market infrastructure group is currently studying laws and regulations in this area.

\subsection{CONDUCT REGULATION}

Conduct regulation is designed to maintain market integrity against irregular behaviours such as insider dealing, market manipulation, and other fraudulent and unfair dealings. Market integrity therefore supports participant confidence in financial market operations. These regulations carry sanctions against entities and individuals. In terms of accounting standards, the IFRS facilitates the cross-border movement of capital through the passporting rights regime, and enforcement against accounting fraud and irregularity aim at maintaining participant confidence. Insider dealing regulations aim at creating a level playing field, and market manipulation levels the playing field while addressing market stability issues. Therefore, stock exchange interconnections reveal which laws regulate and which agencies enforce the law. This area creates public

${ }^{76}$ Directive 2009/44/EC amends the Settlement Finality Directive and the Financial Collateral Arrangements Directive. 
power. The more interconnected markets become, the higher the degrees of shared regulatory and enforcement power become. Even though regulations are imposed at the EU level to crack down on forms of market misconduct, such as market abuse, insider dealing and accounting fraud, market abuse and insider dealing still require further convergence among member states. Therefore, supervisory convergence will be necessary to facilitate market interconnection.

\subsection{LEGAL REGIME GOVERNING JURISDICTION}

\section{AND APPLICABLE LAW}

No model law addresses conflicts in the laws that govern interconnections. Each country retains jurisdiction over activities occurring in their territory. Home regulators assert enforcement power over market activities. Even though passporting rights allow securities admitted for trading to be traded on a market outside the home country, the host country exerts power over how sales are conducted. The home country retains control over solvency requirements. However, in regard to clearing, the issue becomes more contentious. Who has the power to regulate off-shore clearing? This issue relates clearing houses regulation when the United Kingdom, which clears most of the Euro-denominated derivatives, leaves the European Union. Currently, the UK can clear those securities despite the European Central Bank holds a contrary view over off-shore clearing issues. It is envisaged that the European Central Bank will insist on the clearing venues, i.e. CCPs being located within the Euro-zone or a direct oversight into the UK CCPs when the UK leaves the European Union. It will not be sufficient for the UK to rely on the 'equivalence regime' so as to allow CCPs located in the UK to clear Euro-denominated securities. The rationale behind such a location policy of the European Central Bank is that, in time of crisis, the Bank will act as the lender of last resort to provide liquidity. Hence, those CCPs of substantial systemic importance will need to be come under the supervision of ECB.

Furthermore, the differences in the market abuse regime can lead to further regulatory divergence. It is not clear whether the reliance on the equivalence regime will be an adequate solution to ensure market stability in an interconnected market. 


\section{OUTLOOK FOR EXCHANGE INTERCONNECTION}

This article identifies the models of interconnection currently used and the legal obstacles to creating more integrated capital markets led by exchange operators. It shows that interconnection, as far as the equity market is concerned, remains a challenge technically and legally, as well as for broader policy issues. For most markets, an integrated common trading platform that connects two or more markets to realise synergies has not been achieved - the exception is the Euronext UVP model. Whether the non-silo model drives or complicates interconnection at both the domestic and cross-border levels remains a question.

Exchange operators form part of the critical financial infrastructure and are highly regulated. However, different exchange operators engage in different financial activities and have different risk profiles. Regulators may not allow home market participants to participate in activities without approval or regulation. For instance, home traders may not trade on a platform outside the local jurisdiction. This defeats the goal of interconnection where traders should be allowed to engage in direct trade on a foreign platform outside their own country. On the clearing side, few jurisdictions have implemented rules on interoperability or open access, and this increases the cost of cross-border trade. Some jurisdictions also consider participation in a foreign CCP risky when the foreign CCP is not subject to the home CCP requirements.

On the policy argument side, there are also questions about the impact of interconnection on the local economy. Would interconnection result in a concentration of capital and financial services, contributing to an unbalanced global economic development? And, if so, what new models of stock exchange interconnection can bring about a distributed and shared economy?

\section{LIST OF REFERENCES}

[1] (2003) Entente peu cordiale. Economist. [online] Available from: http://www.economist. com/node/1883659 [Accessed 23 September 2017].

[2] (2017) The Custodian-bank Business: A Big Deal Roils the Industry's Usually Placid Waters. The Economist. [online] Available from: http://www.economist.com/news/ finance-and-economics/21716051-big-deal-roils-industrys-usually-placid-waterscustodian-bank-business [Accessed 23 September 2017]. 
[3] (2011) EMCF Says Yes to CCP Interoperability. Global Investor. 245, p. 43.

[4] Ackerly, D. T. and Pan, E. J. (2002) Dual-listing Securities in Europe and the United States. In: Sarah Bolton (ed.) The Complete Guide to Listing on London Stock Exchange. Royal Tunbridge Wells: ISI Publications Ltd.

[5] ASEAN Capital Markets Forum (ACMF). (2016) ACMF Action Plan 2016-2020. [online] Available from: http://www.theacmf.org/ACMF/upload/acmfactionplan2016-2020.pdf [Accessed 23 September 2017].

[6] ASEAN Capital Markets Forum (ACMF). (2016) The Implementation Plan. [online] Available from: http://www.theacmf.org/ACMF/report/ImplementationPlan.pdf [Accessed 23 September 2017].

[7] Banker (2007) LSE/Borsa Italiana talks, 157 (997), pp. 14-16.

[8] De Meijer, C. (2010) Are We Facing European CCP Interoperability Regulation?. Journal of Securities Operations \& Custody, 3 (1), pp. 55-65.

[9] Directive 2003/71/EC of the European Parliament and of the Council of 4 November 2003 on the Prospectus to be Published when Securities are Offered to the Public or Admitted to Trading and Amending Directive 2001/34/EC. Official Journal of the European Union 31 December. Available from: http://data.europa.eu/eli/dir/2003/ 71/oj [Accessed 23 September 2017].

[10] Directive 2013/50/EU of the European Parliament and of the Council of 22 October 2013 amending Directive 2004/109/EC of the European Parliament and of the Council on the harmonisation of transparency requirements in relation to information about issuers whose securities are admitted to trading on a regulated market, Directive 2003/71/EC of the European Parliament and of the Council on the prospectus to be published when securities are offered to the public or admitted to trading and Commission Directive 2007/14/EC laying down detailed rules for the implementation of certain provisions of Directive 2004/109/EC. Official Journal of the European Union 6 November. Available from: http://data.europa.eu/eli/dir/2013/ 50/oj [Accessed 23 September 2017].

[11] Eurex Exchange. Eurex/KRX Link. [online] Available from: http://www.eurexchange. com/exchange-en/products/eurex-krx-link [Accessed 22 September 2017].

[12] Euroclear and Oliver Wyman (2016) Blockchain in Capital Markets: the Price and the Journey. Available from: http://www.dltmarket.com/docs/BlockchainInCapital Markets-ThePrizeAndTheJourney.pdf [Accessed 22 September 2017]. 
[13] European Securities and Markets Authority (ESMA). (2015) Final Report: Draft Regulatory Technical Standards on European Electronic Access Point (EEAP). [online] Available from: https://www.esma.europa.eu/sites/default/files/library/2015/11/20151460_-_esma_final_report_on_draft_rts_on_eeap.pdf [Accessed 23 September 2017].

[14] European Securities and Markets Authority (ESMA). (2015) Regulatory Technical and Implementing Standards - Annex I: MiFID II/MiFIR. [online] Available from: https://www.esma.europa.eu/sites/default/files/library/2015/11/2015-esma1464_annex_ i_-_draft_rts_and_its_on_mifid_ii_and_mifir.pdf [Accessed 23 September 2017].

[15] European Securities and Markets Authority (ESMA). (2017) MiFID II: ESMA Issues Final Specifications for Non-equity Tape Test. [online] Available from: https://www.esma. europa.eu/press-news/esma-news/mifid-ii-esma-issues-final-specifications-non-equitytape [Accessed 23 September 2017].

[16] Euronext. (2017) Euronext London. [online] Euronext. Available from: https://www.euro next.com/nl/listings/euronext-london [Accessed 20 September 2017].

[17] Euronext. Universal Trading Platform - New Trading Safeguards. [online] Euronext. Available from: https://www.euronext.com/en/node/11277

[Accessed 23 September 2017].

[18] Farrell, S. (2014) Too Important to Fail: Legal Complexity in Planning for the Failure of Financial Market Infrastructure. Journal of International Banking Law and Regulation, 29 (8), pp. 461-470.

[19] Ferran, E. (2007) Cross-border Offers of Securities in the EU: the Standard Life Flotation. European Company and Financial Law Review, 4 (4), pp. 461-490.

[20] Ferrarini, G. (2002) Pan-European Securities Markets: Policy Issues and Regulatory Responses. European Business Organization Law Review, 3 (2), pp. 249-292.

[21] Ferrarini, G. and Moloney, N. (2012) Reshaping Order Execution in the EU and the Role of Interest Groups: from MiFID I to MiFID II. European Business Organization Law Review, 13 (4), pp. 557-597.

[22] Fleischer, H. and Schmolke, K. U. (2011) The Reform of the Transparency Directive: Minimum or Full Harmonisation of Ownership Disclosure?. European Business Organization Law Review, 12 (1), pp. 121-145.

[23] Flinders, K. (2008) London Stock Exchange Gains Clearing Technology. Computer Weekly, p. 6.

[24] Geranio, M. (2016) Evolution of the Exchange Industry: from Dealers' Clubs to Multinational Companies. Switzerland: Springer International Publishing. 
[25] Grant, J. (2015) Singapore urges closer ASEAN markets integration. Financial Times. Available from: https://www.ft.com/content/50d42aa6-10d1-11e5-9bf8-00144feabdc0 [Accessed 20 September 2017].

[26] Himaras, E. (2010) Super-CCP Model Could Spur Interoperability: ISDA. Derivatives Week, p. 15.

[27] HKEX-SSX Stock Connect (2017). [online] Hong Kong Exchanges and Clearing Limited. Available from: http://www.hkex.com.hk/eng/csm/index.htm\# [Accessed 20 September 2017].

[28] International Organization of Securities Commissions. (1998) International Disclosure Standards for Cross-Border Offerings and Initial Listings by Foreign Issuers. [online] Available from: http://www.iosco.org/library/pubdocs/pdf/IOSCOPD81.pdf [Accessed 23 September 2017].

[29] Jing, L (2015) Taiwan-Japan ETF Cross-listing Scheme Under Way. Financial Times. Available from: http://www.ft.com/cms/s/0/8f265346-36ac-11e5-b05b-b01debd57852. html?ft_site=falcon\&desktop=true\#axzz4tQzFpt1I [Accessed 22 September 2017].

[30] Karmel, R. S. (2012) IOSCO's Response to the Financial Crisis. Journal of Corporation Law, 37 (4), pp. 849-902.

[31] Köppl, T. V. and Monnet, C. (2007) Guess What: It's the Settlements! Vertical Integration as a Barrier to Efficient Exchange Consolidation. Journal of Banking $\mathcal{E}$ Finance, 31 (10), pp. 3013-3033.

[32] LCH The Markets' Partner. (2016) Regulatory Framework and QCCP Status of LCH. [online] Available from: http://www.lch.com/documents/731485/762558/regulatoryframework-and-qccp-status-of-lch-final.pdf/5d274c8f-03bb-4647-a69e-ecf0000ad365 [Accessed 23 September 2017].

[33] Loh, J. (2016) Taiwan and Singapore Ink Trading Link. Global Capital (1442).

[34] London Stock Exchange Group. (2015) MIFID II: An Update on its Status and Impact. [online] London Stock Exchange Group plc. Available from: http://www.lseg.com/ markets-products-and-services/post-trade-services/unavista/resources/mifid-ii-updateits-status-and-impact [Accessed 23 September 2017].

[35] London Stock Exchange Group. (2017) Norwegian Equity Derivatives. [online] London Stock Exchange Group plc. Available from: http://www.lseg.com/derivatives/lsedm/ products/equity-derivatives/norwegian-equity-derivatives

[Accessed 20 September 2017]. 
[36] MacDonald, A. (2007) LSE Snags Borsa Italiana, Beating Out NYSE Euronext. The Wall Street Journal, Eastern Edition, 249 (146).

[37] Mägerle, J. and Nellen, T. (2011) Interoperability Between Central Counterparties. Swiss National Bank Working Papers. 12, pp. 1-28.

[38] Mortensen, S. (2015) Reviewing the Implementation of T+2, the Impact on the Industry and What Comes Next (T2S). Journal of Securities Operations $\mathcal{E}$ Custody, 7 (4), pp. 312-318.

[39] Murray, H., Pham, T. P. and Singh, H. (2016) Latency Reduction and Market Quality: The Case of the Australian Stock Exchange. International Review of Financial Analysis, 46, pp. 257-265.

[40] Park, C.-Y. (2013) Asian Capital Market Integration: Theory and Evidence. [online] Asia Development Bank Economics Working Paper. Available from: http://www.adb.org/ sites/default/files/publication/30284/ewp-351.pdf [Accessed 23 September 2017].

[41] Pownall, G., Vulcheva, M. and Wang, X. (2014) The Ability of Global Stock Exchange Mechanisms to Mitigate Home Bias: Evidence from Euronext. Management Science, 60 (7), pp. 1655-1676.

[42] Singapure Exchange. (2016) Taiwan Stock Exchange and Singapore Exchange Sign Strategic Partnership Agreement, TWSE Subsidiary to Join SGX as Remote Trading Member. [online] Singapore Exchange Ltd. Available from: http://www.sgx.com/wps/wcm/connect/sgx_ en/home/higlights/news_releases/Taiwan-Stock-Exchange-and-Singapore-Exchangesign-Strategic-Partnership-Agreement [Accessed 23 September 2017].

[43] Stiglitz, J. E. (2010) Risk and Global Economic Architecture: Why Full Financial Integration May Be Undesirable. The American Economic Review, 100 (2), pp. 388-390.

[44] StockMarket.com. (2017). Taiwan Stock Exchange [online] StockMarketClock. Available from: https://www.stockmarketclock.com/exchanges/twse

[Accessed 23 September 2017].

[45] Tapking, J. and Yang, J. (2006) Horizontal and Vertical Integration in Securities Trading and Settlement. Journal of Money, Credit \& Banking, 38 (7), pp. 1765-1795.

[45] The Association of Southeast Asian Nations (ASEAN). (2015) ASEAN 2025: Forging Ahead Together. [online] The ASEAN Secretariat: Jakarta. Available from: http://asean.org/storage/2015/11/67.-December-2015-ASEAN-2025-Forging-AheadTogether-2nd-Reprint.pdf [Accessed 23 September 2017].

[46] The Giovannini Group. (2003) Second Report on EU Clearing and Settlement Arrangements. [online] Directorate-General for Economic and Financial Affairs, 
European Commission. Available from: http://ec.europa.eu/internal_market/financial markets/docs/clearing/ second_giovannini_report_en.pdf [Accessed 23 September 2017].

[47] The Financial Services Act 2012 (c. 21). United Kingdom of Great Britain and Northern Ireland. London: The Stationery Office. In English. Available from: http://www.legislation.gov.uk/uksi/2015/1755/pdfs/uksi_20151755_en.pdf [Accessed 23 September 2017].

[48] The Transparency Regulations 2015, SI 2015/1755. United Kingdom of Great Britain and Northern Ireland. London: The Stationery Office. In English. Available from: http://www.legislation.gov.uk/uksi/2015/1755/pdfs/uksi_20151755_en.pdf [Accessed 23 September 2017].

[49] TWSE. (2016) Taiwan Stock Exchange and Singapore Exchange sign Strategic Partnership Agreement, TWSE subsidiary to join SGX as remote trading member. [press release] 27 January. Available from: http://www.twse.com.tw/en/about/press_room/tsec_news_ detail.php?id=18183

[50] Wan, W. (2017) Cross-Border Public Offering of Securities in Fostering an Integrated ASEAN Securities Market: The Experiences of Singapore, Malaysia and Thailand. Capital Markets Law Journal, 12 (3), pp. 381-411.

[51] Zwick, S. (2006) Futures: News, Analysis \& Strategies for Futures, Options \& Derivatives Traders, 35 (4), p. 14. 